\author{
St ud i P hiloso phic a \\ Wratis l avi e n s i a \\ vol. XVI, fasc. 3 (2021) \\ https://doi.org/10.19195/1895-8001.16.3.8
}

\author{
MATEUSZ KOTOWSKI \\ ORCID: 0000-0002-1782-6365 \\ Politechnika Wrocławska
}

\title{
Czy teza o niedookreśleniu teorii przez dane doświadczenia czyni sukcesy nauki cudem?
}

Does the uderdetermination thesis make success of science a miracle?

Abstract: In his book Struktura rewolucji relatywistycznej i kwantowej w fizyce [The Structure of Relativistic and Quantum Revolution in Physics] Wojciech Sady presents a view on the thesis of underdetermination, according to which it should be regarded as a pseudoproblem of contemporary philosophy of science. I reject this view and suggest that Sady's argumentation against the thesis of underdetermination is tantamount to attacking a straw man. This is because he argues against its correctness by pointing to the incorrectness of the conclusions he unjustifiably draws from it.

Keywords: underdetermination, scientific development, scientific revolution

Po niemal sześciu dekadach od publikacji Struktura rewolucji naukowych Thomasa S. Kuhna wciąż kształtuje nasze myślenie o nauce. Co prawda przedstawiona w tej pracy wizja rozwoju naukowego szybko okazała się pod wieloma względami zbyt radykalna, by wytrzymać krytykę, liczne z prezentowanych w niej tez zostały w mniej lub bardziej zniuansowanej formie wchłonięte przez główny nurt refleksji nad nauką. To ostatecznie w dużej mierze dzięki pracy Kuhna intelektualny mainstream zaczął dystansować się od scjentyzmu, akceptując ograniczenia tak zwanej metody naukowej i doceniając rolę, jaką w rozwoju wiedzy naukowej odgrywaja czynniki pozaempiryczne i pozalogiczne ${ }^{1}$. Niemniej zdaniem niektórych autorów,

1 Oczywiście scjentyzm znajdował się pod ostrą krytyką już od końca XIX wieku, a Kuhn był u jego wcześniejszych krytyków poważnie intelektualnie zadłużony. Niemniej pozostaje faktem społecznym, 
w swojej krytyce obiegowego obrazu nauki Kuhn i jego następcy posunęli się zbyt daleko, w rezultacie raczej zaciemniając i zniekształcając obraz rozwoju naukowego, niż przybliżając nas do zrozumienia rządzących nim mechanizmów. Niewątpliwie zalicza się do tych autorów Wojciech Sady, który udowodnił to w swojej Strukturze rewolucji relatywistycznej $i$ kwantowej $w$ fizyce $e^{2}$. W pracy tej, prowadząc wykład na temat historii tytułowych wydarzeń, podejmuje polemikę z Kuhnem oraz postkuhnowskimi filozofami, którzy jego zdaniem dalece wyolbrzymili rolę, jaką w rozwoju wiedzy naukowej odgrywają wyobraźnia twórcza i kreatywności badaczy oraz inne tak zwane czynniki pozanaukowe. W polemice stara się przekonać czytelnika, że wydarzenia, które zwykliśmy postrzegać jako rewolucyjne, wcale takiego charakteru nie miały - a przynajmniej nie w znaczeniu, jakie pojęciu rewolucji nadawał Kuhn — lecz że dochodziło do nich w rezultacie stopniowych zmian, które były rezultatem konsekwentnego stosowania przez społeczność badaczy dedukcyjnych wnioskowań w oparciu wiedzę zastaną i wyniki eksperymentów, nie zaś wskutek przebłysków geniuszu jednostek obdarzonych wybitną wyobraźnią nakazujących im tę zastaną wiedzę zarzucić na rzecz rozwijania radykalnie nowatorskich koncepcji.

Mimo iż od ukazania się książki Kuhna powstało już bardzo wiele prac krytycznie odnoszących się do jego koncepcji, Struktura rewolucji relatywistycznej $i$ kwantowej w fizyce Wojciecha Sadego to z pewnością pozycja wartościowa, oryginalna i dostarczająca tego typu narracji o historii nauki, jakich potrzebujemy dla lepszego jej zrozumienia. Niemniej, krytykując koncepcję radykalną, Sady w mojej ocenie sam przejawia w swojej książce skłonność do formułowania pewnych zbyt daleko idących sądów. W rezultacie, uzasadniając swoje podstawowe tezy dotyczące charakteru rozwoju naukowego, poświęca po drodze zbyt wiele na ołtarzu lepszej sprawy. Jedną z ofiar jest teza o niedookreśleniu teorii przez dane doświadczenia i to właśnie losowi, jaki spotkał ją w pracy Sadego, poświęcę tu uwagę.

\section{Czym się różni niedookreślenie teorii przez dane doświadczenia od jednorożców?}

Przypomnijmy w telegraficznym skrócie, że zgodnie z tezą o niedookreśleniu teorii przez dane doświadczenia (dalej: tezą o niedookreśleniu) dla każdej teorii zgodnej z dowolnym skończonym zbiorem danych doświadczenia możliwe (czyli co najmniej niewykluczone) jest sformułowanie teorii alternatywnej, zgodnej z tym samym zbiorem danych, lecz różniącej się w zakresie postulowanych praw, ontologii itp. (To jedno możliwych sformułowań zagadnienia). Mimo iż wypowiedzi Sadego sugerują, że z tezą o niedookreśleniu można się zgadzać albo nie (na przykład kiedy pisze on o jej ,zwolennikach”), sama w sobie jest ona raczej wprost konsekwencją charakteru logicznych relacji między zawierającą twierdzenia uniwersalne teorią naukową, a jednostkowymi zdaniami o faktach, które ją potwierdzają. (Popularną ilustracją

że to właśnie w jego sformułowaniu wiele z tez podważających nowożytny ideał nauki przeniknęło do mainstreamowego dyskursu, a popularność jego teorii otworzyła drogę do głównego nurtu wielu innym koncepcjom postrzeganym jako względem niej komplementarne lub ją rozwijające.

2 W. Sady, Struktura rewolucji relatywistycznej i kwantowej w fizyce, Kraków 2020. 
tego zagadnienia jest tak zwany problem doboru krzywej zwracający uwagę na fakt, że przez dowolną skończoną liczbę punktów można poprowadzić nieskończenie wiele krzywych). Właściwie postawione pytanie brzmi zatem nie czy teza o niedookreśleniu jest poprawna, czy też nie, lecz w jakim stopniu należy się nią przejmować; to jest, w jakim stopniu mówi ona jedynie o logicznie niezabronionych możliwościach, a $\mathrm{w}$ jakim stopniu zachodzenie niedookreślenia uwidacznia się $\mathrm{w}$ realnej praktyce naukowej i stanowi problem dla rozwijajacych swoje dyscypliny badaczy. Sady daje czytelnikowi do zrozumienia, że wielu filozofów przejęło się tą tezą dalece za bardzo, podczas gdy nie należy przejmować się nią wcale.

Istotnie, dyskutujący problem tezy o niedookreśleniu autorzy bywali już krytykowani za przywiązywanie zbytniej wagi do tego, co stanowi jedynie „czysto logiczną" możliwość. Ian Hacking, przykładowo, zarzucał nadto przejętym zagadnieniem niedookreślenia, że roztrząsają problem wyboru między potencjalnie nieskończenie wieloma zgodnymi z dostępnymi danymi teoriami, podczas gdy naukowcy mają zwykle trudności ze sformułowaniem choć jednej zgodnej z wynikami eksperymentów teorii. Podobnie wypowiada się Sady, wskazując, że pracującym niezależnie od siebie badaczom zdarza się częściej dochodzić do zbieżnych wniosków niż różnych konkurencyjnych teorii. W tej retoryce niedookreślenie traktowane jest niczym jednorożce - może i w jego istnieniu nie ma niczego sprzecznego, ale kto by się nimi na poważnie przejmował?

Niemniej upierać się, że niedookreślenie, nawet jeśli z logicznego punktu widzenia zachodzi, nie realizuje się nigdy w żaden sposób w nauce, to zaprzeczać faktom. To prawda, że nie doczekaliśmy się jak na razie zbyt wielu opisów nietrywialnych z metodologicznego punktu widzenia przypadków zachodzenia niedookreślenia. Przykłady dotyczące możliwości generowania nieskończenie wielu modeli tej samej teorii są z punktu widzenia problemu formułowania i wyboru teorii nieprzekonujace (choć z punktu widzenia innych problemów niekoniecznie, o czym za moment), ponieważ udowadniają tyle, że teorie mogą być empirycznie niedookreślone ze względu na te swoje części, które nie posiadają empirycznych konsekwencji ${ }^{3}$. Podobnie nieprzekonujace w tym kontekście są argumenty, że niedookreślenie ujawnia się ex post, kiedy starsza teoria okazuje się niedookreślona względem nowszej ${ }^{4}$. Nie jest jednak tak — jak wydaje się sugerować Sady — że ,zwolennicy tezy o niedookreśleniu" rozprawiają tylko o tym, co potencjalnie czy logicznie możliwe. Jesteśmy bowiem w stanie wskazać przypadki opartych na błędnych założeniach, lecz równocześnie eksperymentalnie potwierdzanych i predykcyjnie płodnych teorii; dobrego przykładu dostarcza tu teoria dyfrakcji światła Kirchhoffa ${ }^{5}$. Innymi słowy to, że

3 Tak jest w przypadku popularnego przykładu możliwych modeli układu słonecznego w fizyce klasycznej sformułowanego przez B.C. van Fraassena w To Save the Phenomena, „The Journal of Philosophy" 18 (1976), s. 623-632.

4 Mam tu na myśli sformułowany przez P.K. Stanforda argument z niedostrzeżonych możliwości (unconceived alternatives). Zob. P.K. Stanford, Refusing the Devil's Bargain: What kind of underdetermination should we take seriously?, „Philosophy of Science” 3 (2001), s. S1-S12.

5 Ciekawe omówienie tego przypadku można znaleźć w J. Saatsi, P. Vickers, Miraculous Success? Inconsistency and Untruth in Kirchhoff's Diffraction Theory, „The British Journal for the Philosophy of Science" 1 (2011), s. 29-46. 
niedookreślenie przynajmniej czasami uwidacznia się w rzeczywistym procesie badań naukowych, należałoby raczej uznać za ustalone, nawet jeśli wciąż można argumentować, że ujawniona skala problemu nie czyni go z punktu widzenia rozwoju nauki szczególnie istotnym.

\section{Czego teza o niedookreśleniu nie mówi o formułowaniu teorii}

Podstawowy argument Wojciecha Sadego przeciwko tezie o niedookreśleniu dotyczy odkryć równoległych. Komentując badania Robinsona, Cavendisha i Coulomba nad oddziaływaniami między ładunkami elektrycznymi czy rozwijanie elektrodynamiki Maxwella przez Voigta, Lorentza i Larmora, wskazuje, że badacze ci dochodzili do podobnych czy wręcz takich samych wniosków, podczas gdy w świetle tezy o niedookreśleniu taki zbieg okoliczności zakrawać by musiał na cud. Sugeruje bowiem, iż zgodnie z tą tezą powinniśmy oczekiwać, że uczeni badający niezależnie od siebie te same zjawiska dochodzić będą raczej do wniosków radykalnie odmiennych (skoro mają nieskończenie wiele możliwości uzgadniania teorii z danymi) ${ }^{6}$.

Jednak teza o niedookreśleniu mówi wyłącznie o tym, co możliwe. Z samego uznania jej słuszności w żadnym razie sugerowane przez Sadego oczekiwania nie wynikają — tym bardziej jeśli uwzględni się cały kontekst procesu naukowego. Innymi słowy nic w tej tezie nie sugeruje, że proces formułowania teorii i uzgadniania ich z danymi polega na dowolnym wyznaczaniu krzywych przez zbiory punktów. Jeśli zaś tylko uwzględnić kontekst rzeczywistej praktyki naukowej, należy stwierdzić, iż fakt odkryć równoległych, bardziej niż niezachodzenia niedookreślenia, dowodzi tego, co dla Sadego stanowi punkt wyjścia, czyli kolektywnego charakteru poznania naukowego. Z niezrozumiałych dla mnie względów autor Struktury rewolucji relatywistycznej ściśle wiąże tezę o niedookreśleniu z krytykowanym przez siebie mitem nieskrępowanej wyobraźni twórczej. Tymczasem jeśli poznanie naukowe ma istotnie charakter kolektywny — jak zresztą doskonale pokazuje to Sady — i jeśli członków naukowych kolektywów łączą warunkujące ich poznawczo wspólne przekonania co do natury przedmiotu badań i metod badawczych, to nie ma w tym nic dziwnego, że niezależnie od siebie dochodzą oni do zbieżnych wniosków na temat tych samych zjawisk. Niedookreślenie nie ma tu nic do rzeczy.

\section{Dwa konteksty dyskutowania tezy o niedookreśleniu}

W kontekście uwag Wojciecha Sadego na temat tezy o niedookreśleniu warto, jak sądzę, zwrócić uwagę, że w dyskusjach wokół tej tezy mogą pojawiać się pewne nieporozumienia związane z tym, że jej implikacje mają znaczenie dla dwóch różnych grup zagadnień. Upraszczając nieco, możemy rozróżnić między nimi, nazywając jedne metodologicznymi, drugie zaś epistemologicznymi. Choć w obu przypadkach punktem wyjścia jest dostrzeżenie co najmniej logicznej możliwości formułowania

${ }^{6}$ Zob. W. Sady, Struktura rewolucji relatywistycznej $i$ kwantowej w fizyce, s. 33, 106, 213-214. 
różnych, empirycznie równoważnych teorii, obie grupy zagadnień są od siebie w dużej mierze niezależne i prowokują różne pytania.

Z metodologicznego punktu widzenia będą to przede wszystkim pytania o pozaempiryczne kryteria, które powinny kierować formułowaniem i wyborem teorii. Choć zbywanie tego problemu jako wydumanego w świetle realnej praktyki naukowej byłoby zbyt pospieszne, z pewnością powinniśmy naszą ocenę jego powagi uzależniać od wyników analizy tej praktyki pod jego kątem. Jeśli ta istotnie pokazuje nam, że uczeni niezwykle rzadko stają przed koniecznością wyboru między empirycznie równoważnymi teoriami czy modelami, a gdy już się to zdarza, to dotyczy raczej (jak sugeruje Sady) koncepcji spekulatywnych, które nie generuja testowalnych przewidywań, wówczas istotnie można argumentować, że niedookreślenie ani nie stanowi realnego wyzwania dla praktyki naukowej, ani, w konsekwencji, nie ma większego znaczenia dla naukowego rozwoju. To na ten wymiar zagadnienia zwraca uwage Sady, kiedy wskazuje, że rozumując na podstawie wiedzy zastanej i wyników eksperymentów oraz dążąc przy tym do formułowania możliwie najprostszych matematycznie ujęć badanych zjawisk, uczeni mają mocno zawężone pole manewru, przez co problem niedookreślenia ich nie dotyczy.

Niemniej z epistemologicznego punktu widzenia równie istotne jak pytania o kryteria akceptacji teorii mogą być dla nas pytania o ich status poznawczy. Uzasadnić, że teoria zasługuje na akceptację, a to, że jest to teoria choćby w przybliżeniu prawdziwa, to wszak nie to samo i w tej różnicy ujawnia się różnica w postrzeganiu konsekwencji tezy o niedookreśleniu, a perspektywa formułowania potencjalnie nieskończenie wielu różnych empirycznie równoważnych teorii nabiera innego znaczenia. U podstaw naszego przekonania (o ile je żywimy), że nasze najlepsze teorie naukowe są co najmniej w przybliżeniu prawdziwe leży bowiem ich sukces predykcyjny. Dopuszczenie możliwości formułowania teorii odmiennych pod względem postulowanych ontologii, lecz predykcyjnie równie skutecznych, musi być więc dla żywiących tego rodzaju przekonania niepokojące. Stwierdzenie, że uczeni nie formułują na ogół tego typu konkurencyjnych teorii, ponieważ są ograniczeni zastanym stanem nauki, stanowi zaś tu marne pocieszenie.

\section{Podsumowanie}

Przedstawioną przez Wojciecha Sadego krytykę teorii Kuhna i pewnych popularnych przekonań postkuhnowkiej filozofii nauki można potraktować jako potrzebne wiadro zimnej wody na głowy tych, którzy w krytyce obiegowego obrazu poznania naukowego posuwają się za daleko. Istotnie bowiem, choć nie jest to miejsce, by to uzasadniać, intelektualny klimat poskuhnowskiej filozofii nauki sprzyjał i wciąż sprzyja przecenianiu roli, jaką w procesie powstawania wiedzy naukowej odgrywają czynniki pozaempiryczne. Niemniej, jak starałem się pokazać, w tym studzącym zapale Sady sam zapędza się zbyt daleko, bagatelizując autentyczne (nawet jeśli nieraz przeceniane) problemy metodologiczne i epistemologiczne, których dostrzeżenie legło u początku słusznego końca nowożytnego ideału nauki. Teza o niedookreśleniu jest jedną z niewinnych ofiar tych zapędów. Niewinnych podwójnie. Po pierw- 
sze, krytyka, jaką Sady kieruje pod jej adresem, jest zwyczajnie nieuzasadniona, a wręcz stanowi przykład atakowania chochoła, sprowadza się bowiem ostatecznie do wyciągania z niej wniosków, które z niej nie wynikają, i podważania jej na podstawie błędności tych wniosków. Po drugie, teza o niedookreśleniu, choć Sady zdaje się przekonany, że jest inaczej, jest kompatybilna z przedstawianym przez niego obrazem rozwoju naukowego, zatem obrona trafności tego obrazu wcale nie wymaga jej podważenia.

\section{Bibliografia}

Fraassen B.C. van, To Save the Phenomena, "The Journal of Philosophy" 18 (1976), s. $623-632$.

Sady W., Struktura rewolucji relatywistycznej i kwantowej w fizyce, Kraków 2020.

Saatsi J., Vickers P., Miraculous Success? Inconsistency and Untruth in Kirchhoff's Diffraction Theory, "The British Journal for the Philosophy of Science” 1 (2011), s. $29-46$.

Stanford P.K., Refusing the Devil's Bargain: What kind of underdetermination should we take seriously?, „Philosophy of Science” 3 (2001), s. S1-S12. 